\title{
Why Is Financial Stability a Goal of Public Policy?
}

\author{
By Andrew Crockett
}

1 number of developments in recent years have combined to put the issue of financial stability at the top of the agenda, not just of supervisory authorities, but of public policymakers more generally. These developments include: the explosive growth in the volume of financial transactions, the increased complexity of new instruments, costly crises in national financial systems, and several high profile mishaps at individual institutions.

The growth in the volume of financial transactions and the increasing integration of capital markets have made institutions in the financial sector more interdependent and have brought to the fore the issue of systemic risk. International capital flows, though generally beneficial for the efficient allocation of savings and investment, now have the power in unstable conditions to undermine national economic policies and destabilize financial systems.

$\overline{\text { Andrew Crockett is General Manager at the Bank for }}$ International Settlements. He presented this paper at the Federal Reserve Bank of Kansas City's 1997 symposium, "Maintaining Financial Stability in a Global Economy," in Jackson Hole, Wyoming, August 28-30, 1997. The views expressed are those of the author and do not necessarily reflect those of the BIS or the Federal Reserve System. Helpful comments on an earlier draft of this paper were provided by Svein Andresen, Claudio Borio, Peter Dittus, Danile Nouy, Patrick Honohan and Bill White.
The increased complexity of new instruments makes it harder for senior management in financial firms, let alone supervisory authorities, to understand intuitively the risks to which the institutions concerned are exposed. There are fears that the models underlying the pricing of the new instruments may not be sufficiently robust, that the mathematics of the models may have become disconnected from the realities of the marketplace, or that the operational controls within financial institutions may be inadequate to control the resultant risks.

The crises in financial systems that have occurred have demonstrated the close linkages between financial stability and the health of the real economy. In Mexico, for example, what began as a currency crisis led to a serious recession and created huge strains in the banking system, further deepening the recession. The consequences of the Mexican crisis destabilized several other Latin American countries, notably Argentina, and threatened for a while to have even wider repercussions. In industrial countries, financial strains in Scandinavia and Japan, among others, had adverse consequences for the real economy.

Lastly, there have been a number of wellpublicized losses at individual institutions, due to the breakdown of operational or other controls. Episodes such as Drexel Burnham, Procter \& 
Gamble, Orange County, Metallgesellschaft, Barings, Daiwa, and Sumitomo, though reasonably well contained, demonstrate how quickly losses can mount, and illustrate the systemic risks that would be inherent in a larger scale mishap.

The central case for making the health of the financial system a public policy concern rests on two propositions: firstly, that, left to itself, the financial system is prone to bouts of instability; and secondly, that instability can generate sizable negative spillover effects (externalities). It will be the purpose of this paper to examine these propositions more closely, and in the light of this examination, to consider what forms public policy intervention in the financial sector might take. More specifically, I will address the following questions: what do we mean by financial stability? Why should official intervention (as opposed to reliance on market forces) be required to promote stability? And what concrete approaches can be employed?

\section{WHAT IS FINANCIAL STABILITY?}

A distinction is commonly made nowadays between monetary stability and financial stability (interestingly, this distinction would not have been so easily recognized a generation ago, either by economists or public officials). Monetary stability refers to the stability of the general price level; financial stability to the stability of the key institutions and markets that go to make up the financial system. While these are conceptually separate objectives of policy, the linkages between the two are now increasingly recognized. ${ }^{1}$

The debate on monetary stability has progressed further and its definition has reached a greater degree of consensus than is the case with financial stability. Nobody disputes that the avoidance of excessive inflation is an appropriate objective. And nobody doubts that it is public policy (specifically, monetary policy) that ulti- mately determines the inflation rate. Remaining debates, as became evident last year at Jackson Hole, surround issues such as how to accurately measure inflation; what, within a relatively narrow range (usually 1-3 percent), should be considered an optimal inflation rate; whether the objective should be expressed in terms of the inflation rate or the price level, and how quickly one should return to price stability after having been forced away from it. ${ }^{2}$

No such general consensus applies in the case of the definition of financial stability. For the time being, at least, each writer can supply his own. In my case, I will take financial stability to apply to both institutions and markets. In other words, stability requires (i) that the key institutions in the financial system are stable, in that there is a high degree of confidence that they can continue to meet their contractual obligations without interruption or outside assistance; and (ii) that the key markets are stable, in that participants can confidently transact in them at prices that reflect fundamental forces and that do not vary substantially over short periods when there have been no changes in fundamentals.

This does not, however, provide a full definition. Which are the "key institutions" whose stability is important? And what is the degree of price stability in financial markets that is required?

Stability in financial institutions means the absence of stresses that have the potential to cause measurable economic harm beyond a strictly limited group of customers and counterparties. Occasional failures of smaller institutions, and occasional substantial losses at larger institutions, are part and parcel of the normal functioning of the financial system. Indeed, they serve a positive function by reminding market participants of their obligation to exercise discipline over the activities of the intermediaries with whom they do business. 
Similarly, stability in financial markets means the absence of price movements that cause wider economic damage. Prices can and should move to reflect changes in economic fundamentals. And the prices of assets can often move quite abruptly when something happens to cause a reassessment of the future stream of income associated with the asset, or the price at which this income stream should be discounted. It is only when prices in financial markets move by amounts that are much greater than can be accounted for by fundamentals, and do so in a way that has damaging economic consequences, that one is justified in talking about "instability" or "crisis" in the financial system.

A practical issue that is worth addressing at this point is whether all financial institutions and all markets should be treated similarly. Are problems in the banking sector to be considered in the same light as problems at nonbank financial institutions? Is the failure of a big bank the same as that of a small bank? And should central banks be as concerned about excessive volatility in asset prices as they are about instability among financial institutions? These are issues that have been, and remain, controversial.

Consider first the question of which institutions are important for financial stability. This raises two further issues: are banks special? And are some institutions "too big to fail"? Two reasons are usually given for believing that banks warrant special treatment in the preservation of financial stability. ${ }^{3}$ The first is that banks' liabilities are repayable at par on demand, while their assets are typically comparatively illiquid. This makes them more liable to runs that cause illiquidity and even insolvency. The second is that banks remain responsible for the operation of the payment system. This means that difficulties at one institution are transmitted, semi-auto- matically, to the rest of the financial system, with the risk, at the extreme, that the payments system could seize up.

Both of these reasons continue to have force, though perhaps not to the same extent as previously. While illiquid loans remain a disproportionate share of banks' assets, holdings of marketable securities have tended to increase. And the "moneyness" of banks' liabilities may have become less of a distinguishing characteristic, as banks increase their reliance on marketable claims to meet funding requirements, and nonbank institutions issue liabilities that are repayable on demand. Banks continue to dominate the payments system, and the failure of one bank immediately generates losses to those banks exposed to it in the settlement system. Cascading losses through these arrangements have the potential to undermine the payments systems, which is the basis for monetary exchange in all economies. But interlocking claims and settlement exposures among other entities at the core of the financial system have grown sizably as nonbank financial intermediaries have come to greater prominence. These have increased the potential for knock-on effects among them.

The conclusion is that banks remain "special," in that instability in the banking system has a greater capacity to generate systemic contagion than difficulties elsewhere in the financial sector. But the distinctions are becoming more blurred, with problems at key nonbank institutions having growing potential for significant spillover consequences.

In many respects size has become more important than an institution's formal character in determining its systemic significance. Regulators frequently deny that there is a "too big to fail" doctrine. One can understand why they do, since to make it explicit would court moral hazard. Still, it is only realistic to recognize that 
certain institutions are so central to the financial system that their failure would constitute a systemic crisis. Their obligations to counterparties are so large that failure to discharge them would cause widespread contagion. This group of institutions includes both banks and nonbanks.

Next, what about price volatility in asset markets? How much price movement can take place before we should classify markets as being "unstable"? And which markets are of particular concern for the health of the financial system and the economy more generally?

There are obviously no hard-and-fast answers to these questions. Any price movements that exceed what can be justified on grounds of changing fundamentals have the potential to result in resource misallocation. Sustained price volatility that generates uncertainty, leading to an unwillingness to enter into long-term contracts, hampers economic performance through discouraging the mobilization and allocation of savings through the financial system. And sudden or sharp price movements that place the liquidity or solvency of prudently run financial institutions at risk have more immediate dangers.

As to which markets should be the focus of concern, once again the criterion should be the capacity to cause wider economic damage. Financial and other asset markets, because of their broad linkages to saving and investment decisions, obviously have a greater potential impact on other macroeconomic variables than do developments in markets for goods and services. This impact can occur through wealth effects, as the prices of financial assets change; through changing the expected returns on savings and investment; or through generalized effects on consumer and business confidence.

A further point concerns the capacity for contagion among financial markets. Just as difficul- ties at one financial intermediary appear to have the effect of undermining confidence more generally, so experience suggests that sharp movements in one market can destabilize others. Examples of this phenomenon include the broadly similar movements in international equity prices in 1987 , following the price break on Wall Street; the general upward movement in bond yields in 1994; and the spread of exchange rate difficulties in Europe in 1992-93 and in Southeast Asia in 1997.

In conclusion, there is still no clear-cut definition of what constitutes financial instability. What may distinguish the financial system from other areas of economic activity, however, is the potential for healthy flexibility to develop-in a short period of time-into more troublesome instability and eventually, in extreme circumstances, into crisis. This is because precautionary action taken by individuals in the face of asymmetric information can in certain circumstances have the effect of amplifying, rather than dampening, natural volatility. This potential brings us closer to an understanding of why the maintenance of stability is often considered to be a natural responsibility of public authorities.

Assessing the point at which movements in asset prices, or in the financial position of intermediaries, risk becoming self-perpetuating is obviously a matter of judgment. Because the costs of mistakes are so high, it is of key importance to understand the dynamics of the process. It is also important to come to an assessment of the ways in which the financial instability interacts with the real economy to intensify (or moderate) an initial shock. It is for this reason that, whatever the specific arrangements in place in any country to monitor or underwrite the health of individual institutions, there needs to be close cooperation between the authorities responsible for the supervision of individual institutions, those responsible for broader systemic stability, 
and those concerned with stability in prices and the real economy.

\section{WHY IS OFFICIAL INTERVENTION REQUIRED TO PROMOTE STABILITY?}

There can be little doubt that financial stability, properly defined, is a "good thing." It creates a more favorable environment for savers and investors to make intertemporal contracts, enhances the efficiency of financial intermediation and helps improve allocation of real resources. It provides a better environment for the implementation of macroeconomic policy. Instability, on the other hand, can have damaging consequences, from the fiscal costs of bailing out troubled institutions to the real GNP losses associated with banking and currency crises.

The only qualification to be made is that stability must not be confused with rigidity. Market prices must be allowed to move as supply and demand conditions change. And financial institutions should not be prevented from going out of existence when they are unable to make a profit. The trick is to permit the necessary flexibility in market prices and structures, without generating instability that has damaging consequences on confidence and real economic activity.

Financial stability is a public good in that its "consumers" (i.e., users of financial services) do not deprive others of the possibility of also benefiting from it. In this sense, public authorities have an interest in seeing that it is "supplied" in an appropriate quantity. This does not mean, however, that public authorities should necessarily intervene in financial markets so as to promote stability. There is no public agency directly concerned with stability in the market for foodstuffs or automobiles (although govern- ments generally accept a responsibility for health and safety and for competition). Is finance any different?

It cannot be denied that all financial instability has costs for someone. The collapse of a financial firm imposes direct costs on shareholders, who lose their investment; on employees, who lose their jobs; and on depositors and unsecured creditors, whose claims may be forfeit. Instability in asset prices creates losses for those whose investments prove unsuccessful. In this (i.e., the direct or "private" costs of instability), financial firms and markets are not qualitatively different from other sectors of the economy. And while there are always pressures to compensate private losses, it is generally assumed that the public interest is served best by allowing market disciplines to work - unless there is evidence of market failure.

In what follows, I will examine the argument that the financial system is particularly subject to market failure, and that the consequences of such failure justify public policy intervention. It will be convenient to divide this discussion into two parts: that concerned with the potential for instability at financial institutions; and that concerned with excessive volatility in prices in financial markets.

\section{Instability at financial institutions}

The reasons why difficulties at a financial firm may give rise to public policy concerns may be grouped under several (overlapping) heads:

(a) Losses to depositors and other creditors may be exacerbated because of the unique vulnerability of financial institutions to "runs."

(b) The scope for losses to spread to other financial institutions through "contagion" or direct exposures is high. 


\section{Table 1}

\section{EQUITY PRICES IN 1987 AND BOND YIELDS IN 1994}

$\begin{array}{r}\text { Equity price movements in } \\ 2 \text { weeks of October 1987* } \\ \hline\end{array}$

United States

Japan

Germany

France

United Kingdom

Italy

Canada

Netherlands

Belgium
$-20.2$

$-12.2$

$-14.2$

$-16.7$

$-24.8$

$-11.3$

$-18.5$

$-18.9$

$-10.7$
Bond yield rise end-January through end-July 1994 (basis points) $\dagger$

* 9th to 23rd October 1987.

$\uparrow$ Ten-year benchmark.

Sources: National sources.

(c) There may be budgetary costs from the perceived need to protect depositors or bailout troubled institutions.

(d) There may be more widespread macroeconomic consequences from instability in the financial sector.

(e) A loss of confidence in financial intermediation may lead to financial "repression" resulting in suboptimal levels of savings and misallocation of investment.

The first two of these points concern the potential for an "instability bias" in the financial system; the last three to the external costs generated by such instability. Let us now consider them in slightly more detail.

"Runs" and the protection of individual institutions. There are two broad reasons why the authorities may wish to be involved with the stability of individual institutions (other than contagion risk, which is dealt with below). One rests on the vulnerability of banks to runs; the other on economies of scale in monitoring the behavior of complex firms.

A well-known feature of banks is that they issue liabilities that are redeemable on demand at par, while they hold longer term assets that are less readily marketable and have an uncertain value. Under normal circumstances, this does not pose a major problem, since deposit withdrawals are subject to the law of large numbers and well-managed loans that are held to maturity are mostly repaid at face value. A bank's holding of capital covers the risk of loan loss, and a cushion of liquid assets is sufficient to preserve confidence in its ability to meet withdrawals.

If, however, something happens to disturb confidence, the situation can be destabilized. Depositors perceive that those who withdraw 
their funds first will be able to do so without loss or penalty; those who delay may find that the bank's capital has been eroded by a "fire-sale" of less marketable assets. What this means is, firstly, the value of a bank (like other firms) is greater as a going concern than it is in a forced liquidation. Secondly, because of the leverage inherent in banks' operations, forced liquidation is more likely than in the case of nonfinancial firms. This argues in favor of an outside agent to preserve potentially solvent institutions as going concerns, or else to intervene to gradually wind down firms that have become insolvent.

A slightly different argument for intervention to protect depositors is that they have inadequate information to protect themselves. Monitoring financial institutions is costly, and pooled monitoring may be more efficient than individual monitoring. (Note that this argument may apply to all firms, not just those, like banks, whose liabilities are repayable at par on demand.) In this view, the public authorities are performing a service (like that of a rating agency) that it would be too difficult or too costly for individual depositors to perform for themselves. This argument can be given a political slant by recognizing that, to be realistic, certain depositors will always act foolishly when faced with the incentive of high returns. Since political pressure to provide compensation for losses is bound to ensue, it is better for the authorities to step in to avert losses, or rationalize the process by which compensation is provided.

\section{"Contagion" effects at other financial institu-} tions. Potentially more serious than the losses that accrue to individual depositors at a failed institution is the danger that difficulties may be propagated more widely. Such contagion can take place through two main channels: firstly, the pattern of interlocking claims among financial institutions; and secondly, the potential for difficulties at one institution to provoke a loss of confidence in others thought to be similarly placed.

There can be little doubt that the exposure of financial firms to other financial intermediaries has grown dramatically in recent years. A major factor has been the increase in trading activities. Daily foreign exchange trading has increased threefold over the last decade and stood at $\$ 1.25$ trillion in 1995. Well in excess of 80 percent of these trades are between dealing counterparties. Derivatives and securities trading has grown even faster and is also dominated by interdealer activity. The place where the resulting interintermediary exposures get concentrated is the interlocking network of payments and securities settlement systems. Although individual exposures are of short duration, at any point in time they are very large in size. In many cases, the unsecured exposure of financial institutions to a single counterparty exceeds capital. It is this fact that has led some observers to conclude that a disruption transmitted through the payment system is the largest single threat to the stability of the financial system. ${ }^{4}$

Contagion can also occur indirectly, when strains at one financial institution provoke a loss of deposits from, or an unwillingness to enter into transactions with, other firms that are also thought to be vulnerable. Following the Barings collapse, for example, a number of small to medium-sized investment banks in London and elsewhere were reported to have suffered deposit withdrawals, even though there was nothing to suggest that they had incurred losses similar to Barings'. In other words, contagion can be indirectly as well as directly induced.

Contagion is one of the basic reasons why public authorities are concerned with the health and survival of individual financial institutions. This relates to the "public good" aspect of financial stability. Confidence in the financial system 
benefits individual participants without imposing costs on others. If the failure of one institution causes a contagious loss of confidence elsewhere, the adverse consequences to the system as a whole may be much greater than those resulting from the initial disruption.

Resolution costs. Turning now to the spillover consequences of instability, the transfer costs of resolving financial crises are the most readily quantifiable, and in many ways the most striking. To public policy officials, the costs that fall on the public budget surely provide the most persuasive evidence of the need to do whatever is necessary to strengthen financial systems.

The U.S. public is acutely aware of the savings and loan debacle of the 1980s, the resolution costs of which are estimated at anywhere between 2 percent and 4 percent of GDP. These costs, however, pale in comparison with the fiscal costs incurred in a number of other countries. ${ }^{5}$ In France, the losses incurred by a single bank, Credit Lyonnais, are now put at some $\$ 30$ billion, or over 2 percent of GNP. Honohan estimates the fiscal costs of resolving crises in developing countries alone as being as much as $\$ 250$ billion. ${ }^{6}$ A World Bank Study estimates that 14 countries had to devote more than 10 percent of GNP to the resolution of banking sector crises (Table 2$).^{7}$ And a by now well-known IMF study concludes that almost three-quarters of IMF member countries encountered "significant" banking sector problems during the period 1980-96; of these as many as one-third warrant the designation "crisis." ${ }^{8}$ Part of the resolution costs of these crises fall on the banking system and its clients. More frequently, however, the government budget is left to pick up the lion's share.

GNP costs of financial instability. The resolution costs of financial sector crises are, of course, transfer costs. They cannot be taken as an accurate guide to losses in economic welfare, which could be either greater or smaller. They could be smaller than the transfer costs if the real assets financed by failed banks remained in existence and continued to yield productive services. On the other hand, the cumulative misallocation of financial resources represented by bad loans suggests that the overall loss to society from inefficient financial intermediation may have been even larger than the losses that eventually fell on the budget or on the shareholders and other claimants of banks. How can one go about assessing the macroeconomic costs of instability?

Even if instability does not lead to crisis, they can make it harder for the authorities to gauge the appropriateness of a given policy stance. Financial fragility complicates the interpretation of the indicators used to guide monetary policy decisions. Somewhat more seriously, weaknesses at financial institutions can limit the willingness to lend, thus creating "head winds" for the expansion of demand. Overall economic performance suffers as a result.

Where financial difficulties are more serious, the impact on GNP can be larger and more direct, whether or not the authorities decide to support the financial system. In Mexico, for example, the interaction of financial sector difficulties and a currency crisis led to a sharp setback to GNP. By mid-1995 industrial output in Mexico had fallen 12 percent from its level two quarters earlier. Even in Argentina, which successfully defended its exchange rate, GDP is estimated to have temporarily fallen some 7 percent below trend as a result of the "tequila effect." The banking crisis of the 1980s in Chile saw output growth drop from 8 percent in the five years preceding the crisis to only 1 percent in the five years after it.

Among industrial countries, it is harder to 
Table 2

Country (time period of crisis)

\section{Latin America}

Argentina (1980-82)

Chile (1981-83)

Venezuela (1994-95)

Mexico (1995)

Africa

Benin (1988-90)

Cote d'Ivoire (1988-91)

Mauritania (1984-93)

Senegal (1988-91)

Tanzania (1987-95)

Middle East

Israel (1977-83)

Transition countries

Bulgaria (1990s)

Hungary (1995)

Industrial countries

Spain (1977-85)

Japan (1990s)

a $1982-85$.

b Accumulated losses to date.

c In 1987.

d In 1983.

e Estimate of potential losses.

Source: Goldstein (1997) based on Caprio and Klingebiel (1996a).
Estimate of total losses/costs (percentage of GDP)

$$
\begin{gathered}
55 \\
41^{\mathrm{a}} \\
18 \\
2-15^{\mathrm{b}} \\
\\
17 \\
25 \\
15 \\
17 \\
10^{\mathrm{c}} \\
\\
30^{\mathrm{d}} \\
\\
14 \\
10 \\
\\
17 \\
10^{\mathrm{e}}
\end{gathered}
$$

$12-15^{\mathrm{b}}$ detect cause-and-effect relationship between financial instability and GDP. In the United States, the savings and loan crisis had little measurable impact on growth, costly though it was to the budget. In Nordic countries and in Japan, the consequences are more readily apparent. Growth in Finland averaged 4.5 percent in the years preceding the outbreak of the banking crisis, and was minus 4.0 percent in the three succeeding years (though doubtless not all of the difference is attributable to financial difficul- ties). In Sweden and Norway, there were economic downturns following the strains in the banking system, though again other factors were also at work. And in Japan, the "head winds" caused by financial sector weaknesses held growth in the mid-1990s below the underlying potential of the economy.

It bears repeating here that the relationship between financial instability and macroeconomic instability is two-way. Macroeconomic insta- 
bility is usually a major factor in financial difficulties, often because an unsustainable expansion induces unwise lending. Credit-fueled "bubbles" in financial asset and property prices frequently play a contributory role, especially when a large share of lending is used to finance the acquisition of real estate or financial assets whose price is, for a time, rising rapidly. ${ }^{9} \mathrm{~A}$ recession then reveals serious weakness in lending portfolios. When the financial system encounters difficulties, problems can quickly worsen macroeconomic performance. Weakened intermediaries cease to lend, losses in the financial sector create negative wealth or income effects, generalized uncertainty inhibits investment, and the public sector is often forced to rein in real expenditure to help offset the budgetary cost of increased transfers.

Instability and the development of the financial sector. Beyond the direct effects of financial instability on real economic activity, there can be indirect adverse consequences for longer run growth potential if financial intermediation is stunted. As Akerlof has shown, in any market where participants have asymmetric information, moral hazard and adverse selection reduce exchange below levels that could be beneficial if market participants had better information (the market for lemons). The market for intertemporal exchange is characterized by extreme asymmetry of information between providers of funds and potential borrowers. The potential negative consequences are, however, offset by the existence of specialized intermediaries. Financial intermediaries perform the role of agents for lenders, screening out uncreditworthy borrowers, monitoring borrowers' performance after a loan is made, adding creditworthiness through the commitment of their own capital, and creating liquidity through providing for the ready marketability of claims.

All of this, however, depends upon the preser- vation of confidence in the stability of the network of financial intermediaries: if lenders lose confidence in the continued stability of the institutions to whom they have entrusted their funds, or in the integrity of the markets in which they have invested, they will seek to reduce their exposure and place their assets elsewhere. In the limit, they may choose consumption over saving, or may place their savings in nonproductive but "safe" forms (such as precious metals). If this happens, the contribution of the financial sector in providing improved methods of risk pricing and management, and in adding liquidity and creditworthiness, will be much diminished. Mishkin indeed defines a financial crisis as "a disruption to financial markets in which adverse selection and moral hazard problems become much worse, so that financial markets are unable to channel funds efficiently to those who have the most productive investment opportunities." 10

\section{Instability in financial markets}

While there is broad (though not universal) acceptance that the stability of financial institutions should be an objective of public policy, this is much less true with regard to financial asset prices or financial flows. The majority view is that free markets are the best guarantors of equilibrium in prices, and that official intervention should be limited to removing market imperfections, e.g., by promoting the disclosure of relevant information and preventing the emergence of monopoly practices. Yet financial markets can, in principle, be subject to the same kind of "instability bias" and adverse spillovers that affect financial institutions.

Instability bias arises if a disturbance affecting prices generates forces creating further moves in the same direction. These are generally based on extrapolative expectations, which can result from asymmetric information, reinforced by herd instincts. Certain technical features of mar- 
kets, such as margin requirements, can also play a role. In a rising market, those who invest on margin find their net worth rising, and are thereby enabled to make further leveraged purchases, pushing prices still higher. The opposite effects come into play in a falling market, with margin calls forcing liquidation of holdings and exacerbating price declines.

The importance of such instability biases are very hard to assess on a priori grounds. The sudden drop in equity prices in 1987 suggests that they can sometimes be significant, though the relative infrequency of such occurrences provides some reassurance. Swings in exchange rates could be taken as evidence that similar pressures work in currency markets; though full-blown currency crises are more apt to be result of attempts to defend a fixed rate at an unsustainable level.

Volatility in financial asset prices has the capacity to create "spillover" effects of various kinds. Firstly (and perhaps least troublesome), is the added difficulty it creates for the authorities in formulating macroeconomic policies. Movements in asset prices influence all of the channels by which monetary policy traditionally affects the real economy: the interest rate channel, the wealth channel, the exchange rate channel. Moreover, they can, if severe, have pervasive effects on confidence. There is at present a lively debate about whether and how monetary policy should respond to asset price movements. The fact that the debate is still unresolved is evidence of the uncertainties created for policymakers when financial markets are unstable.

Another type of spillover effect occurs when asset price movements undermine the stability of financial institutions. This can happen if intermediaries are heavily exposed to certain categories of assets (e.g., equities or real estate), or if their lending is secured on such assets. It can also occur if financial institutions have mismatched foreign currency or interest rate books, or if higher volatility suddenly increases the costs of hedging options positions.

Lastly, asset price volatility can create real economic costs if the authorities are led to take extreme measures to restore stability. Perhaps the most prominent examples of such costs occur in currency crises. Instability in foreign exchange markets is almost invariably accompanied by sharply higher interest rates in the country whose currency is under downward pressure. And higher interest rates usually provoke a downturn in economic activity, whether accompanied and exacerbated by a financial sector crisis or not.

What are the specific markets that are particularly vulnerable to instability, and what is the nature of the spillover effects? Let us briefly consider four.

Firstly, the foreign exchange market. Two types of instability should be distinguished: the turmoil that surrounds speculation against a pegged exchange rate; and the volatility that seems to characterize floating rates. The defense of pegged rates, especially when it is ultimately unsuccessful, is most likely to be classified as a currency “crisis." In such a case, it can be argued that the problem is as much one of policy as of market instability. Should the authorities have selected a fixed rate regime? Should they have changed the peg (or the regime) earlier? Should they have pursued a different mix of policies? Some have argued, however, that attacks on a fixed peg can also be speculatively induced. ${ }^{11}$ Where there are dual or multiple equilibria in exchange rate relationships, the movement from one to another may owe more to market dynamics than to fundamentals. 
Where exchange rates are floating, volatility is harder to explain, especially when movements in fundamentals are modest. Swings in relative real values among the U.S. dollar, Deutsche Mark and Japanese Yen have approached 50 percent or more in the past decade and a half. Such swings complicate macroeconomic policies; generate the potential for resource misallocation and give rise to protectionist pressures. While it can be argued that exchange markets are responding to policy divergences (actual and expected), the link is often not at all clear.

Secondly, instability in equity markets can also have external consequences. Stock market volatility can undermine the stability of financial institutions who are directly or indirectly exposed to equity prices; exacerbate the investment cycle (via Tobin's “q"); and, if prices fall sharply, have adverse effects on confidence. However, although stock market crashes have a fascination for lay opinion, the impact of equity price instability has for most of the time been relatively mild. This may be because there are nonlinearities at work. Modest movements in equity values do little if any harm; but a larger movement has a disproportionately greater potential both to set up self-perpetuating forces and to do real economic damage.

Thirdly, much the same can be said of price fluctuations in bond markets. Despite the generalized run-up in bond yields in 1994, adverse spillovers were rather well contained. So long as the central bank is thought able to stabilize inflation, the scope for extreme movements in bond prices is limited.

Fourthly and finally, real estate, though not strictly speaking a financial asset, can be subject to "bubble" phenomena. A real estate bubble complicates the formulation of monetary policy while it is being created, and can leave a string of failures in its wake when it bursts. Some of the difficulties faced in mid-1997 by Southeast Asian economies can be traced, in part to real estate bubbles.

What should be concluded from the foregoing brief survey? If there are disequilibrium tendencies in financial and other asset markets, and if price volatility has had adverse spillover consequences, does this argue for making the stability of asset prices a focus of public policy concern in the same way as the stability of financial institutions?

Here the answer is, at best, not clear-cut. Few economists would be confident that governments could be better at determining equilibrium prices than markets. Even when prices move by an amount that is clearly greater than "fundamentals" justify, it can rarely be said that the price was more appropriate before the move than after it. And frequently, the blame for price volatility is due to unstable policies just as much as to unstable markets. So the broad consensus among economists (with which I agree) is that official policy to stabilize financial asset prices should be focused more on sustainable policies and removing market imperfections, than on direct actions to limit price movements.

One should recognize that there can, occasionally, be exceptions to this general rule. When currencies become substantially misaligned (as in 1985 , say), governments may try to give a lead to markets (albeit through statements concerning policies). And if domestic asset prices were to fall to an extent that threatened financial stability, it would not be surprising to see a policy response aimed at stabilizing prices. In fact, central banks responded to the 1987 stock market crash by easing the provision of liquidity to financial markets. In general, however, official responses to extreme price movements tend to be ad hoc, rather than part of a cohesive "policy" on financial market stability. 


\section{APPROACHES TO ENSURING FINANCIAL STABILITY}

The foregoing section has listed a number of reasons why financial instability has negative externalities. These are probably sufficient to make achieving and maintaining stability a public policy goal. It is of less help, however, in determining how public authorities should promote stability. This section reviews several broad approaches to promoting stability, implying varying degrees of intervention by the authorities. The principal focus is on policies to promote stability at financial institutions, since these have been the subject of more coherent analysis. At the end of the section, however, there are a few observations on preventing instability in key market prices.

\section{Reliance on market forces}

With the possible exception of New Zealand, where certain special circumstances apply, no countries have adopted the position that market forces can be relied on as the sole guarantor of stability at financial institutions. But while official support for the pure market solution is limited, there is a stronger academic tradition in this vein, going back to the free banking school, and finding recent expression in the writing of Dowd. ${ }^{12}$ Other academics have questioned whether the contagion effect that lies behind official concern with systemic stability is in reality all that significant. ${ }^{13}$

The case for the market solution is, to simplify, as follows: when all actors, including depositors, counterparties, managers, and shareholders of financial institutions realize they are "on their own," they will exercise a much higher degree of care, and financial institutions will thereby be forced to operate in a sounder and more prudent fashion. The failure of an individual institution will become less likely, and the risk of systemic contagion will be almost nonexistent. The moral hazard implied by official intervention will be removed, with favorable consequences for the efficiency of resource allocation.

The case against can be put on several levels. Most fundamentally, it is argued that there are events that may occur very infrequently, that cannot be predicted, and that have the capacity to destabilize the financial system if not resisted. These could include political events such as the outbreak of war or the election of radical governments; economic events, such as the 1929 stock market crash; or natural disasters such as a major earthquake in a large metropolitan center. If governments were to stand aside from helping the financial system under such extraordinary circumstances, financial institutions would have to carry such a large cushion of capital as to greatly reduce their capacity to contribute to economic welfare in normal times.

More prosaically, it is pointed out by Goodhart and others that political pressures make it very hard for elected authorities to refuse assistance to institutions whose depositors have powerful electoral influence. ${ }^{14}$ Since most market participants know this, any ex ante announcement by governments not to support the financial system lacks credibility. Moral hazard is not, therefore, avoided. Thus, despite the attraction of reliance on market forces, most observers accept that it is insufficient, by itself, to guarantee stability in all circumstances.

\section{Safety nets}

The most effective way of ensuring continued confidence in financial institutions is to provide their users with some sort of explicit safety net. The main types of safety net are deposit insurance schemes, and the presence of a lender of last resort. The primary drawback of safety nets is moral hazard, which appears in a particularly 
overt form with deposit insurance. Insured depositors have no incentive to monitor the institutions with whom they place their funds. Borrowing institutions are therefore able to pursue risky strategies and, at the limit, to "gamble for resurrection" when their capital has been eroded. The potential for imprudent behavior is exemplified by the savings and loan episode in the United States.

Various means have been suggested to address the moral hazard issue. These include limiting the coverage of deposit insurance, charging riskbased insurance premia, and limiting insurance coverage to a specific category of institutions (100 percent reserve banks). None is entirely satisfactory. Limiting the coverage of insurance schemes means that uninsured depositors can still precipitate a "run" when they fear for bank solvency. Risk-based insurance premia are difficult to calculate on a formulaic basis. And 100 percent reserve banking, despite impressive academic support from Henry Simons to Milton Friedman and James Tobin, has never gained much support. ${ }^{15}$ Probably most observers conclude that 100 percent reserve banks would not be successful in winning a major share of the market during normal times, and therefore the issue of how to safeguard stability at other institutions would not go away.

Lender-of-last-resort support has been a recognized role of central banks since Bagehot. The object is to provide support to solvent but illiquid institutions to avoid the possibility that they would have to liquidate assets in a "fire sale" that would generate losses and lead to an avoidable insolvency. Aside from the practical difficulty of distinguishing between insolvency and illiquidity, the lender-of-last-resort role does not avoid the problem of moral hazard..$^{16}$ One answer to this is "constructive ambiguity"-a phrase made popular by Jerry Corrigan meaning that central banks reserve the right to intervene to preserve stability but give no assurances, explicit or implicit, to individual institutions. Such an approach is intended to make institutions act more prudently by making them uncertain whether they would be rescued in a crisis. In some circumstances, however, "constructive ambiguity" may turn out to be a cloak for "too big to fail," if the lender of last resort is more willing to take the risk of allowing a small institution to go under than a large one.

\section{Regulation}

If there were no safety net, regulation would be justified by the need to protect the interests of depositors and other creditors. With a safety net, the justification shifts to one of protecting the deposit insurance fund (often taxpayers) and avoiding moral hazard. In practice the focus of regulation has shifted significantly over time, and may now be in the process of a further shift. Three different focuses for regulation can be distinguished.

Regulation to protect franchise values. Until about 20 years ago, regulation in most countries had the effect of limiting competition in the financial industry. Entry to the industry was controlled, there were restrictions on interest rate competition, and cartel-type practices were tolerated. In a number of countries, including the U.S. and Japan, there was strict segregation between commercial and investment banking activities. Since franchise values were high as a result, losses were less likely and, when they did occur, more often led to industry-sponsored takeover or rescue than to outright failure.

Several developments in the 1970s and 1980s undermined this form of regulation. The growing dominance of the free market philosophy made protective practices less acceptable. Liberalization and deregulation increased competition which in turn eroded banks' profitability 
and diminished franchise values. With relatively thin capital cushions, this made banks more vulnerable to adverse external shocks. As a result regulation to limit competition and bolster the profitability of financial institutions was no longer a practicable or acceptable means of ensuring systemic stability.

Risk-based capital adequacy. In recent years the dominant form of regulation to promote systemic stability has been risk-based capital adequacy. Instead of limiting banks' activities, regulators have sought to ensure that banks are adequately capitalized against the risks they run. This is the philosophy behind a series of documents issued by the Basle Committee on Banking Supervision. Supervisors have divided assets into a number of "risk classes" and specified the amount of capital to be held against each.

Such an approach has several advantages. The notion of relating capital to risk is in conformity with the reason financial institutions hold capital in the first place. And the increased capitalization of the banking system that has followed from the decisions of the Basle Committee has undoubtedly improved systemic resiliency. Nevertheless, certain aspects of the way the approach has been implemented have drawbacks, which are becoming increasingly recognized.

Firstly, and most importantly, there is the potential for a discrepancy between risk, as calculated by the financial institution itself, and risk as measured by regulatory criteria. To take two obvious examples: the Basle Committee risk weights make no distinction between high and low quality credits within the same risk weight category (e.g., between a AAA borrower and a junk bond issuer); nor do they take account of the possibility of risk reduction through diversification. Most financial firms now find that there is a significant discrepancy between the "economic capital" they consider appropriate to cover the total risk of their portfolio and the "regulatory capital" they are required to hold under the Basle ratios.

This would not matter much from the viewpoint of stability if the only problem were an excess of prudence on the part of supervisors. Indeed, it could well have advantages, since the additional capital cushion required by supervisors could be considered the "price" to be paid for the safety net provided by the lender of last resort. As some writers have pointed out, however, this is not the only implication. Even adjusting for supervisory caution, a portfolio's riskiness may appear significantly different when internal risk models are used than when the Basle risk weights are applied. It is possible for banks with higher risk appetites to deliberately add risk to their portfolios (e.g., through the use of credit derivatives) without having an effect on the regulatory capital required to meet the Basle ratios. ${ }^{17}$

A second problem with the current approach is that it focuses only on certain categories of risk. One gap in the original Basle Accord has now been plugged with the extension of capital requirements to market risk as well as credit risk. But several of the most recent examples of serious losses in the financial sector have come from operational risk (Barings, Daiwa), legal risk (swaps with UK local authorities) and model risk (Metallgesellschaft). As a result of these perceived shortcomings, growing attention is now being given to using regulation to better harness market incentives in support of stability.

Regulation to support market forces. In any market, self-regulation is a powerful force. The strongest incentive to act with prudence and integrity comes from those with most to lose when they fail to do so. Recent thinking has therefore focused on ways of strengthening the incentives 
on individual institutions to manage their own affairs prudently and on their counterparties to exercise appropriate discipline: in the jargon, "incentive-compatible financial regulation." 18

Consider the assessment of risk. The managers of a financial institution have a strong incentive to monitor accurately their risk exposure. It therefore seems likely that an internal assessment of risk will be a better measure than a simplified external formula. This philosophy has been accepted by the Basle Committee and incorporated in the market risk amendment to the Capital Accord. The market risk amendment allows firms to use their own models (subject to external validation) to measure the risk in their trading portfolio then prescribes a "multiplication" factor which translates value at risk into required capital holding.

It seems, therefore, as though the debate is moving towards a distinction between the measurement of risk, which is best done by those who are closest to the portfolio, and have the tools to do it; and the capitalization of risk, decisions on which raise public policy issues. Since the authorities, by underwriting the stability of the financial system are in essence providing financial institutions with catastrophic risk insurance, it is legitimate for them to limit the potential recourse to such insurance by requiring a minimum level of capital holding.

Conceivably, one could go even further and assign responsibility for decisions on capital holding to the private sector as well. This is the philosophy behind the so-called "pre-commitment" approach. An institution would itself choose how much capital it would assign to cover the value at risk in its portfolio. If losses exceeded the calculated probability, then the institution would be subject to some kind of penalty. This is an intriguing idea, though it would present a number of complex practical issues. Moreover, it is not clear that it would lead to an appropriate pricing of the safety net.

The idea of harnessing self-disciplining forces is also behind the proposal of the Group of Thirty to develop industry-led standards for risk management, internal operating controls and public disclosure. ${ }^{19}$ The proposal would call for major international institutions to commit to standards that they would undertake to meet themselves and to require of their counterparties. When endorsed by supervisors, these would then presumably spread, through market pressures, to all institutions. Being developed by practitioners, these standards, it is argued, are more likely to provide an appropriate balance between benefits and costs. In particular, by allowing the industry to propose more efficient ways of reducing risk, they would reduce the danger that firms would cut corners in an effort to avoid burdensome official regulation.

Before ending this section, a word should be added on policies to preserve stability in financial market prices. Theory provides much less help in addressing this issue than that of stability in financial institutions. Certain approaches to providing a more stable market environment would not be controversial. These include the encouragement of stable and sustainable macroeconomic policies; fuller disclosure and dissemination of relevant financial data; and the outlawing of anticompetitive practices in financial markets. Other measures have also attracted a measure of support, such as the use of "circuitbreakers" when prices move by more than a certain threshold amount.

What to do when a significant "bubble" is thought to be developing, or when a bubble bursts, is a matter on which there is little agreement. Public authorities can warn about "irrational exuberance," but central bankers are in general unwilling to adjust macroeconomic 
policy to stabilize financial asset prices. If prices were to fall, the reaction might be different, if only because experience suggests that price falls tend to be more rapid and disorderly than price rises.

\section{CONCLUDING COMMENTS}

There is persuasive evidence that financial stability provides a favorable environment for efficient resource allocation and more rapid economic growth. ${ }^{20}$ Instability has been associated with lower levels of saving and investment, fiscal costs, and setbacks to GNP. It is, therefore, unavoidable that securing stability should be a concern of public policy authorities.

What is less clear, however, is whether the maintenance of stability requires an activist approach on the part of the authorities, or alternatively whether it can best be achieved by reliance on market forces. Arguments against a pure laissez-faire approach include the following: that there are disequilibrium tendencies within the financial system that can, via contagion, turn instability into crisis; and that the costs of a financial crisis for economic welfare are so great that it is irresponsible to take chances. On the other hand, too great a level of support for the financial system, or support in inappropriate ways, can lead to inefficiency and moral hazard.

A consensus therefore seems to be developing among central bankers that regulation should, as far as possible, be directed at reinforcing the self-disciplining tendencies of the market. This probably means less detailed or prescriptive regulation, and a greater reliance on the internal controls of market participants, supported by mechanisms that sharpen the incentive for prudent behavior.

It may be worth ending with a few observations on regulatory structure. A tendency has developed in recent years to draw a distinction between the function of institutional supervision; responsibility for systemic stability; and responsibility for price stability. These are indeed separate functions, and there may be cases in which the pursuit of any one of them is handicapped by the simultaneous pursuit of the others.

There are also powerful linkages, however. Systemic stability is linked to the health of the individual institutions that comprise the system; and instability in the financial system can both cause and be caused by instability in the real economy. What this means is that there must be close collaboration between those responsible for monetary and financial stability, respectively, and that both must be aware of the financial condition of the key institutions. Moreover, in order not to stifle innovation, all concerned need to have a healthy respect for market forces and recognize the need, in a market economy, for bankruptcy as an ultimate sanction for unsuccessful enterprises.

This does not lead to any universally applicable conclusions concerning regulatory structure. It should, however, give pause to those who believe that separating functions is a straightforward and costless measure to tackle perceived shortcomings in present arrangements. 


\section{ENDNOTES}

1 BIS Annual Report, 1996-97.

2 Federal Reserve Bank of Kansas City's 1996 symposium, "Achieving Price Stability," held in Jackson Hole, Wyoming, August 29-31.

3 Goodhart, C.A.E., Philipp Hartmann, David T. Llewellyn, Liliana Rojas-Suares, and Steven R. Weisbrod. 1997. "Financial Regulation: Why, How and Where Now?" Monograph for the Central Bank Governors' Meeting at the Bank of England, June 6.

4 Corrigan, E. Gerald. 1996. "Remarks at the Symposium on Risk Reduction in Payments Clearance and Settlement Systems," New York, Goldman Sachs and Co., January 25.

5 Goldstein, Morris. 1997. "The Case for an International Banking Standard," Institute for International Economics, Washington, D.C., April.

6 Honohan, Patrick. 1996. "Financial System Failures in Developing Countries: Diagnosis and Prescriptions," unpublished manuscript. Washington: International Monetary Fund.

7 Caprio, Gerard, and Daniela Klingebiel. 1996. "Bank Insolvencies; Cross-Country Experience," unpublished manuscript. Washington: World Bank.

8 Lindgren, Carl-Johan, Gillian Garcia, and Matthew Seal. 1995. "Bank Soundness and Macroeconomic Policy." Washington: International Monetary Fund.

9 Borio, C.E.V., N. Kennedy, and S.D. Prowse. 1996. "Exploring Aggregate Asset Price Fluctuations Across Countries: Measurements, Determinants and Monetary Policy Implications.” BIS Economic Papers, no. 40, April.

10 Mishkin, Frederic S. 1991. "Anatomy of a Financial Crisis," National Bureau of Economic Research Working Paper no. 3934.

11 Eichengreen, Barris, and Charles Wyplosz. 1993. "The Unstable EMS," Brookings Papers on Economic Activity, no. 1 , pp. 51-143.
12 Dowd, Kevin. 1988. "Private Money," Institute of Economic Affairs, Hobart Paper, no. 112.

13 Kaufman, George. 1994. "Bank Contagion: A Review of the Theory and Evidence," Journal of Financial Services Research, no. 8, April, pp. 123-50.

14 Goodhart, C.A.E., Philipp Hartmann, David T. Llewellyn, Liliana Rojas-Suares, and Steven R. Weisbrod. 1997. "Financial Regulation: Why, How and Where Now?" Monograph for the Central Bank Governors' Meeting at the Bank of England, June 6.

15 Simons, Henry. 1948. Economic Policy for a Free Society. Chicago: University of Chicago Press. Also, Friedman, Milton. 1959. A Program for Monetary Stability. New York: Fordham University Press. Also, Tobin, James. 1985. "Financial Innovation and Deregulation in Perspective," Bank of Japan Monetary and Economic Studies, no. 3, September, pp. 19-29.

16 Of course, it is usually accepted that the management of a failed institution should forfeit their positions and the shareholders should lose their money: the debate surrounds the extent to which uninsured depositors should be protected.

17 Yellen, Janet L. 1996. “The 'New' Science of Credit Risk Management at U.S. Financial Institutions," presented at the Conference on Recent Developments in the Financial System, Bard College, April 11, and reproduced in BIS Review.

18 Greenspan, Alan. 1996. "Remarks to 32nd Annual Conference on Bank Structure and Competition," Federal Reserve Bank of Chicago, May, and reproduced in BIS Review, No. 58.

19 Group of Thirty. 1997. "Global Institutions, National Supervision and System Risk," A Study Group Report, Washington.

20 King, Robert G., and Ross Levine. 1993. "Finance and Growth: Schumpeter Might Be Right," Quarterly Journal of Economics, August, pp. 717-37. 